\title{
Students' Voice Toward Good English Teachers' Characteristics at Secondary Schools in Indonesia
}

\author{
Sukardi Weda \\ sukardi.weda@unm.ac.id \\ English Department, Faculty of Languages and Literature \\ State University of Makassar
}

\begin{abstract}
This research aims at finding out the secondary school students' voices towards good English teachers' characteristics and the most dominant good teachers' characteristics preferred by the students. This research employed descriptive method supported by descriptive statistics. There were thirty-two students participated in this research who were in the second year in 2012. The instrument used in this research was the checklist in which the students were asked to choose the descriptions which consisted of three choices; disagree, agree, and disagree. The research reports illustrate that students' voices toward good English teachers' characteristics in English as a Foreign Language (EFL) at a secondary school in Indonesia are ranging from explaining lesson objective clearly to provide jokes while teaching. The most dominant good teachers' characteristics preferred by the secondary school students were "gives clear explanation" in which there were $56.25 \%$ students gave "strongly agree" answer. There were also "56.25\% students gave "strongly agree" answer to "the teacher should provide jokes or funny stories in the classroom setting." There were $65.62 \%$ students gave "agree" answer to "the teacher should use a variety of materials." There were $65.62 \%$ students gave "agree" answer to "the teacher should be relaxed and he should create a pleasant atmosphere." Well prepared is also important in the classroom, where there were $62.5 \%$ students gave "agree" answer to this statement. There were $43.75 \%$ students gave "disagree" answer to "gives follow up/feedback." Even though, the "disagree" choice to this statement is highest than other choices in the "disagree" choice but the "agree" and "strongly agree" choice have higher score, because the accumulation of the total score is $56.25 \%$. This means that the teachers need to give feedback to students' works in the classroom.
\end{abstract}

Keywords: students' voice, teachers' good characteristics, EFL, secondary school

\section{INTRODUCTION}

Learning English at secondary schools in Indonesia has been long considered as a mandatory subject. This is because English becomes a very vital language in the world as either English as an International Language (EIL) or English as a means of communication in various activities, in economics and commerce, science and technology, and so on. 
Chew in Dewi argues that in the neighboring country of Singapore, English has been believed as the language of economic development, especially in relation to "foreign investment, international trade, and business.

Because of the importance of English as EIL, each person needs to master it if he or she needs to master the world. Based on this reason, English is placed in the first position to be taught at schools and tertiary levels.

To achieve the curriculum target as stated in the Indonesian constitution and other related laws in education practices in Indonesia. The government of Indonesia, therefore, develops the quality of teaching and learning process and the government also conducts lots of training designed to teachers and language practitioners.

The training and development conducted in English subject are very important because there were a lot of research results reported that the quality of English teaching and learning in Indonesia is low. There are some influencing factors towards the low quality of English teaching and learning process in Indonesia; those factors are the low quality of the English teachers, the students' interest to learn English is low, parents' participation to encourage students' motivation to learn is low, and so on. In line with this, Dardjowidjojo 2000 and Nur 2004 in Larson (2014: 122) argued that the low proficiency in English upon graduation from senior high school is attributed to many factors including: large class sizes, the low English proficiency of teachers, low salary, not enough teacher education to teach the new curriculum and cultural barriers hindering teachers from adopting a facilitator role in English as a foreign language (EFL) class.

One of the main factors to contribute to the quality improvement of the education sector is a teacher. Therefore, teachers need to improve, not only their English competence and performance but also their good characteristics as teachers in the classroom setting. Teachers who have good characteristics can trigger the students' involvement in the classroom.

What are competence and performance?. According to Brown (1994), competence is one's underlying knowledge of the system of a language - its rules of grammar, its vocabulary, all the pieces of a language and how those pieces fit together on the one hand, on the other hand, performance is actual production (speaking, writing) or the comprehension (listening, reading) of linguistic events. 


\section{0| ELT Worldwide Vol. 3 No. 1 April 2016}

What is a teacher's good characteristic? According to Orlando (2013), there are nine characteristics of a great teacher. Those characteristics are: 1) A great teacher respects students, 2) A great teacher creates a sense of community and belonging in the classroom, 3) A great teacher is warm, accessible, enthusiastic and caring, 4) A great teacher sets high expectations for all students, 5) A great teacher has his own love of learning, 6) A great teacher is a skilled teacher, 7) A great teacher can "shift gears" and is flexible when a lesson isn't working, 8) A great teacher collaborates with colleagues on an ongoing basis, and 9) A great teacher maintains professionalism in all areas - from personal appearance to organizational skills and preparedness for each day.

There are two research questions (RQs) of this research which become endeavor to find out the students' opinion towards the teachers' good characteristics. The characteristics hopefully will give insights to English teachers to act as a good role model in the classroom. The RQs are; What are the secondary school students' voices towards good English teachers' characteristics?, and What are the most dominant good teachers' characteristics preferred by the students?

\section{RESEARCH METHOD}

This research employed a descriptive method in which descriptive statistics used to support the data analysis. There were thirty-two students participated in this research. They were in the second year of junior high school (SMP Negeri 36 Makassar). This school is located in the eastern part of Makassar city as the capital city of South Sulawesi Province, Indonesia.

The instrument used in this research was the checklist in which the students were asked to choose the descriptions which consisted of three choices; disagree, agree, and disagree.

\section{RESEARCH FINDINGS}

The research findings reveal that the students chose "agree" and "strongly agree" dominantly to some characteristics in the checklist. There was only one characteristic got $43.75 \%$ in "disagree" choice that is "Gives follow up/feedback." Even though the "disagree" choice has significant but the "agree" and "strongly agree" choice have a higher score because the accumulation of the total score is $56.25 \%$. This means that the teachers need to give feedback to students' works in the classroom. 
From the students' voice, out of 16 teachers' characteristics as stated in table 1, that none of the students gave a response to "disagree" towards "Explains the lesson objective clearly." There were 53.12\% students gave response agree to this item, and $46.87 \%$ of the students gave a response "strongly agree."

For the item "Gives a clear explanation," none of the students gave response to "disagree," there were $43.75 \%$ students gave response to "agree," and there were $56.25 \%$ students gave response to "strongly disagree." This means that the teachers need to give a clear explanation of their materials and procedures of their teaching.

Item number 3, "Explains the lesson systematically," there were $56.25 \%$ of students agreed and $37.5 \%$ of them strongly agree. This reflects that the students expect the teachers to explain the lesson systematically.

Item number 4 shows that there were $50 \%$ students agree to item number 4 and there were $40.62 \%$ of them strongly agree. This symbolizes that the teacher question and student response hopefully can give student - teacher interaction in the teaching and learning process in the classroom.

Item number 5 reveals that there were $40.62 \%$ of the students agreed to the item number 5 , there were $37.5 \%$ of the students strongly agreed to the item number 5 , and there were $12.5 \%$ of them disagreed with item number 5. This illustrates that the students expect the teachers to check the students' understanding towards the materials taught to the students. This is important because the teacher can know whether the students understand the materials or not.

tem number 6 "Motivates the students to be active in learning process/classroom discussion" seems to be important in the learning and teaching process. This is because students' participation in the classroom shows the successfulness of the teaching managed by the teacher. In this item, no students gave "disagree" responses, there were $59.37 \%$ of them gave "agree" responses, and there were $40.62 \%$ of them gave "strongly agree" response. This reveals that the teacher should involve the students in the classroom discussion or talk.

The "Approaches the students" is also good characteristics attributed to a great or good teacher. In this item, there were only $6.25 \%$ of the students gave "disagree" response, there were 40.62 of them gave "agree" response, and there were $53.12 \%$ of them gave "strongly agree" response. 


\section{2| ELT Worldwide Vol. 3 No. 1 April 2016}

For the item "Gives follow up/feedback," there were $43.75 \%$ of the students gave "disagree" response, and there were $50 \%$ of them gave "agree" response, and there were only $6.25 \%$ of the students gave "strongly agree." This seems that feedback is important in the teaching and learning process. This is because feedback gives students' additional explanation and lesson.

Table 1. Students' Voice toward Good Teachers' Characteristics

\begin{tabular}{|c|c|c|c|}
\hline $\begin{array}{c}\text { Item } \\
\text { Students } \mathrm{N}=32\end{array}$ & $\begin{array}{l}\text { Disagree } \\
(\%)\end{array}$ & $\begin{array}{c}\text { Agree } \\
(\%)\end{array}$ & $\begin{array}{c}\text { Strongly } \\
\text { Agree } \\
(\%)\end{array}$ \\
\hline Explains the lesson objective clearly & 0 & 53.12 & 46.87 \\
\hline Gives clear explanation & 0 & 43.75 & 56.25 \\
\hline Explains the lesson systematically & 6.25 & 56.25 & 37.5 \\
\hline Teacher question/student response & 9.37 & 50 & 40.62 \\
\hline Checks to confirm student's understanding & 12.5 & 40.62 & 37.5 \\
\hline $\begin{array}{l}\text { Motivates the students to be active in learning } \\
\text { process/classroom discussion }\end{array}$ & 0 & 59.37 & 40.62 \\
\hline Approaches the students & 6.25 & 40.62 & 53.12 \\
\hline Gives follow up/feed back & 43.75 & 50 & 6.25 \\
\hline $\begin{array}{l}\text { Gives homework assignment/individual or } \\
\text { group task }\end{array}$ & 25 & 59.37 & 15.62 \\
\hline Uses a variety of material & 21.87 & 65.62 & 12.5 \\
\hline Uses audio visual realia & 18.75 & 59.37 & 21.87 \\
\hline Has class management skill & 6.25 & 50 & 43.75 \\
\hline Relaxed, pleasant atmosphere & 0 & 65.62 & 34.37 \\
\hline He or she is well prepared & 6.25 & 62.5 & 31.25 \\
\hline Rewards appropriate performance & 21.87 & 43.75 & 34.37 \\
\hline Provides joke or funny stories while teaching & 9.37 & 34.37 & 56.25 \\
\hline
\end{tabular}

Giving homework assignment or individual tasks to students is also important in the English teaching - learning process. This is because assignment and tasks can improve students' understanding towards the material discussed in the classroom. In this item, the responses from the students are respectively as follows: 59.375 of students agreed, $25 \%$ of them disagreed, and $15.62 \%$ of them strongly agreed. 
Various materials are also expected by the students, this shows that 65.62 of the students agreed, and $12.5 \%$ of the strongly agreed, and there were $21.87 \%$ of them disagreed.

Audiovisual is also important in the teaching - learning process, the students' responses show that there were $59.37 \%$ of the students gave "agree" responses, and 21.875 of them gave "strongly agree" response, and there were only $18.75 \%$ of them gave "disagree" response.

One of the successfulness in the classroom is the way teacher manages the class. In line with this, most of the students gave "agree" and "strongly agree" response. There were $50 \%$ of the students agreed and $43.75 \%$ of them strongly agreed. This illustrates that above $90 \%$ of the students expected that the teacher should have managerial skill in delivering subject in the classroom.

Learning a language, especially English becomes problems by some students or English learners; therefore, the teacher should present the material in a relaxed and pleasant atmosphere. In relation to this item, no students gave "disagree" response on the one hand, but on the other hand, they gave "agree" response: $65.62 \%$ and "strongly agree" response: $34.37 \%$.

The teacher is also expected to be well prepared, in line with this item, the students gave responses respectively; 62.5\% agreed, 32,25\% strongly agreed, and only $6.25 \%$ disagreed. This implies that the teacher as one of determining factors in the learning process needs to prepare himself or herself, as a facilitator, manager, and prompter.

The learning theory suggests that the successful students or the students who have high achievement in the classroom need to be awarded rewards. This reward hopefully can reinforce the students' motivation, interest, and involvement in the English learning process. There were $43.75 \%$ of students agreed on rewards, there were $34.37 \%$ of them strongly agreed on rewards, and there were only $21.87 \%$ disagreed.

Other than those characteristics, joke needs to be considered by the teacher in delivering the materials in the classroom. The results of the research showed that $56.25 \%$ of the students strongly agreed if there is a joke and $34.37 \%$ of them agreed, and only $9.37 \%$ disagreed. 
Chart 1. Percentage Distribution of Students' Responses on Disagree

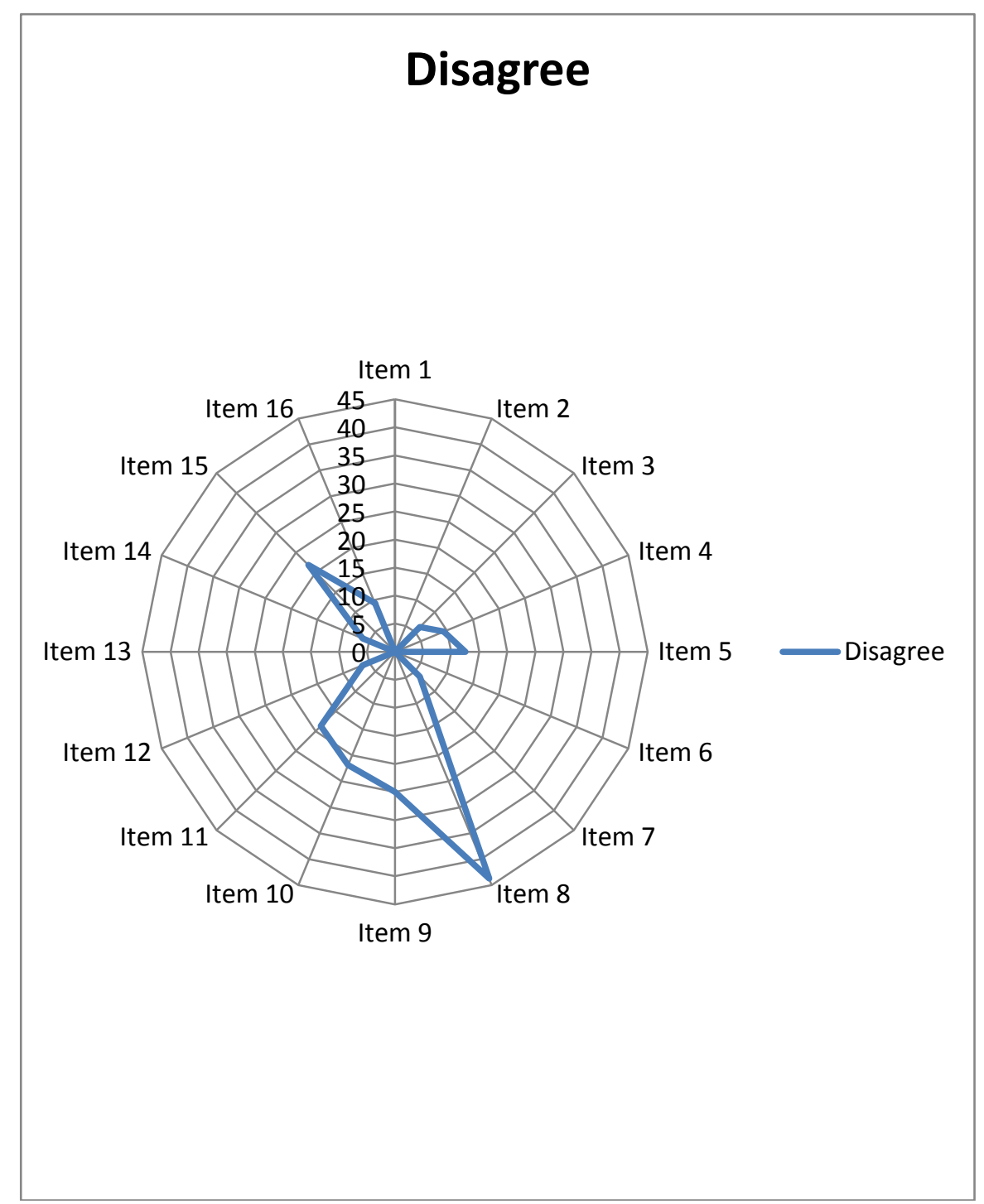

Chart 1 reveals that there were $43.75 \%$ of the students gave "disagree" response to the feedback from the teacher. Chart 2 shows that there are two high scores of "agree" responses. Those are the item "Uses a variety of materials," which were $65.62 \%$ students and item "Relaxed, pleasant atmosphere," which were $65.62 \%$ students. 
Chart 2. Percentage Distribution of Students' Responses on Agree

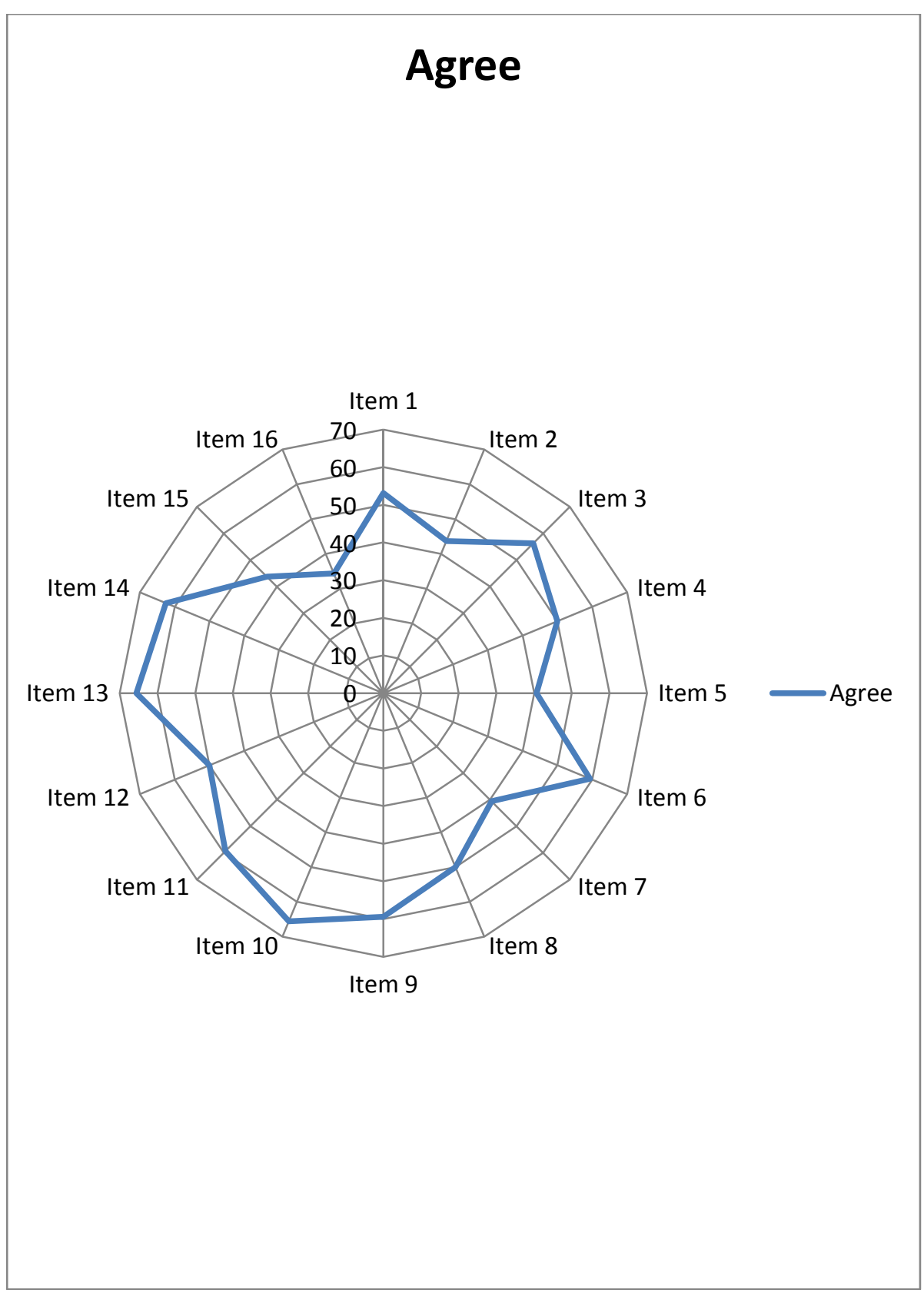

Chart 3 shows that item "Clear explanation," has a high score in which there were $56.25 \%$ students gave "strongly agree" response. 
86| ELT Worldwide Vol. 3 No. 1 April 2016

Chart 3. Percentage Distribution of Students' Responses on Strongly Agree

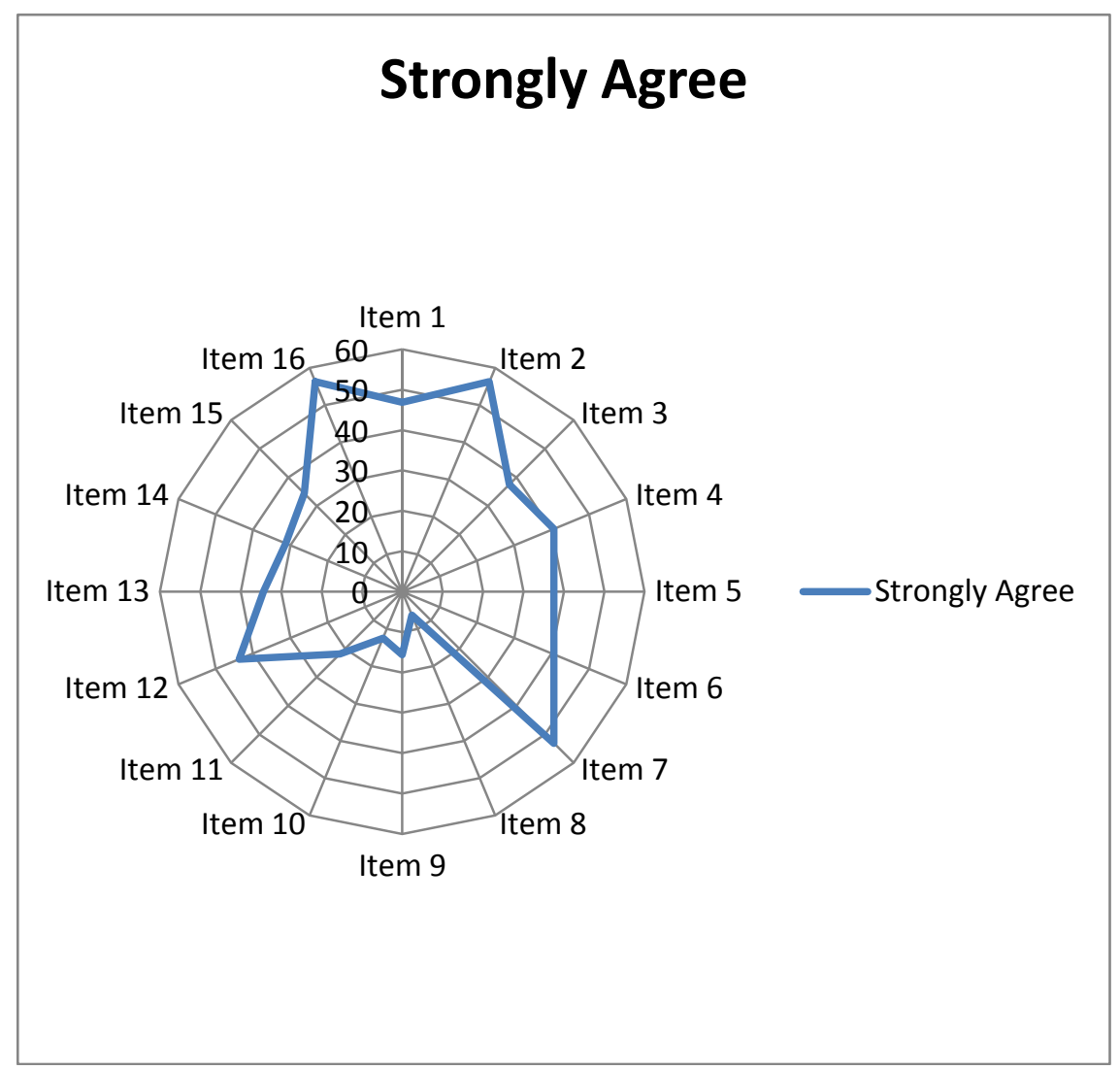

\section{DISCUSSION OF FINDINGS}

Based on the research findings as previously stated, the teacher hopefully explains the lesson objective clearly in the beginning of the class. This students' great expectation revealed in the study that there were $46.87 \%$ strongly agree to the statement and $53.12 \%$ agree to the statement and none of the students disagree with the statement.

The teacher is also recommended to give a clear explanation to the subject. This is because there were $56.25 \%$ gave strongly agree to the statement that the teacher should give a clear explanation, there were $43.74 \%$ agree and none of the students gave disagree answer to the statement. 
For item number 3, "explains the lesson systematically," there were $6.25 \%$ students gave "disagree' response to this item. There were $56.25 \%$ students gave "agree" response, and $37.5 \%$ students gave "strongly agree" response. This means that the students need that the lesson needs to be explained systematically by the teacher.

Item number 4 "teacher question/student response," there were $9.37 \%$ students gave "disagree" response, $50 \%$ of them gave "agree" response and there were $40.62 \%$ gave "strongly agree" response. This means the question and answer session needs to be maintained in the classroom to make rapport between the teacher and the students.

Item number 5, "Checks to confirm student's understanding," was responded by the students in a wide variety of responses. There were $12.5 \%$ of the students gave "disagree" response, "40.62 of the students gave "agree" response, and there were $37.5 \%$ of the students gave "strongly agree" response. If the agree and strongly agree responses are accumulated, the score is $78.12 \%$. This allows the teacher to check his or her students' understanding of the material in the classroom.

None of the students gave "disagree" response to this item, "Motivates the students to be active in learning process/classroom discussion." There were $59.37 \%$ students gave "agree" response and $40.62 \%$ of them gave "strongly agree" response. This illustrates that one of the main duties of the teacher is to motivate his or her students to be involved in the classroom discussion. This is because group discussion is one of the methods to build students' teamwork skill.

The data also reveal that 6.25 of the students gave "disagree" response. There were $40.62 \%$ of the students gave "agree" response, and there were $53.12 \%$ of them gave "strongly agree" response. This symbolizes that the students hope the teacher can approach the students to share, to give, to ask, to answer the comments from the students. The main objective this approach is to know whether the students understand the lesson or not.

There were $43.75 \%$ of the students gave "disagree" response to the item "Gives follow up/feedback," and this is the highest response of the "disagree" choice. There were $50 \%$ of the students gave "agree" response and there were only $6.25 \%$ of them gave "strongly agree" response. This shows that the accumulation between "agree response" and "strongly agree response" is above fifty percent (56.25\%). This means that the students need feedback from the teacher in every lesson. Feedback is a very important aspect in learning process to toil students' comprehension. 


\section{8| ELT Worldwide Vol. 3 No. 1 April 2016}

There were $25 \%$ of the students gave "disagree" response to "give a homework assignment to students". There were $59.37 \%$ of the students gave "agree" response and there were 15.62 of them gave "strongly agree" response. This means that the teacher is recommended to provide a wide variety of homework assignments to students.

There were $21.87 \%$ of the students gave "disagree" response to "uses a variety of material." There were $65.62 \%$ of the students gave "agree" response and there were $12.5 \%$ of them gave "strongly agree" response. This means that the teacher is suggested to employ a wide variety of material in the classroom setting.

There were $18.75 \%$ students disagree to "the use of audiovisual realia" in the classroom. There were $59.37 \%$ of the students "agree" and there were $21.87 \%$ of them "strongly agree" to the use of audiovisual realia in the classroom setting. This illustrates that the teacher is suggested to teach using audiovisual realia.

There were $50 \%$ of the students agree to "has class management skill," and $43.75 \%$ of the students strongly agree with this statement, and there were only $6.25 \%$ of them disagree with this statement. This reveals that the teacher is recommended to manage the class well during the learning - teaching processes.

There were no students who gave response "disagree" to "relaxed, pleasant atmosphere." There were $65.62 \%$ of the students gave "agree" response and there were $34.37 \%$ of them gave "strongly agree" response. This means that the teacher should create a relaxed and pleasant atmosphere in the classroom during the learning teaching processes.

The teacher should be well prepared during the learning - teaching processes. This reason based on the students' responses to "he or she is well prepared." There were $62.5 \%$ of the students gave "agree" response and there were $31.25 \%$ of them gave "strongly agree" response and there were only $6.25 \%$ of them gave "disagree" response.

There were $21.87 \%$ of the students gave "disagree" response to "rewards appropriate performance" and there were $43.75 \%$ of the students gave "agree" response and there were $34.37 \%$ of them gave "strongly agree" response. This illustrates that the teacher should give rewards to students if they are correct in responding the questions. Hence, rewards become reinforcement which stimulates students to learn hard. 
There were $34.37 \%$ of the students gave "agree" response to "provides joke or funny stories while teaching." There were $56.25 \%$ of the students gave "strongly agree" response and there were only $9.37 \%$ of them gave "disagree" response. This reveals that the teacher should give a joke or funny stories in the learning - teaching processes in the classroom setting to avoid students' boring.

\section{CONCLUDING REMARK}

The students' voices towards good English teachers' characteristics are varied ranging from "gives clear explanation" to "provide jokes and funny stories in the classroom."

The most dominant good teachers' characteristics preferred by the secondary school students were "gives clear explanation" in which there were $56.25 \%$ students gave "strongly agree" answer. There were also "56.25\% students gave "strongly agree" answer to "the teacher should provide jokes or funny stories in the classroom setting." There were $65.62 \%$ students gave "agree" answer to "the teacher should use a variety of materials." There were $65.62 \%$ students gave "agree" answer to "the teacher should be relaxed and he should create a pleasant atmosphere." Well prepared is also important in the classroom, where there were $62.5 \%$ students gave "agree" answer to this statement.

There were $43.75 \%$ students gave "disagree" answer to "gives follow up/feedback." Even though, the "disagree" choice to this statement is highest than other choices in the "disagree" choice but the "agree" and "strongly agree" choice have a higher score because the accumulation of the total score is $56.25 \%$. This means that the teachers need to give feedback to students' works in the classroom.

The implication of this research is that the teacher is suggested to give a clear explanation and he or she needs to provide a wide variety of materials in the classroom setting. Jokes or funny stories relating to the topics discussed are also important so that the teacher is recommended to employ these pivotal activities in the classroom. This is because jokes of funny stories can potentially enhance students' motivation and involvement in the learning - teaching processes.

Relaxed and good atmosphere are also vital and they hopefully will give enthusiasm for students to be involved in a variety of learning activities designed to boost students' English communicative competence. 
90| ELT Worldwide Vol. 3 No. 1 April 2016

\section{REFERENCES}

Brown, Douglas. (1994). Principles of Language Learning and Teaching. New Jersey: Prentice Hall Regents.

Dewi, Anita Sartika (NA). "What the Young Generation Perceives in EIL Era: A Qualitative Study of Yogyakarta University Students". In Selected Papers in English Language Teaching. Jakarta: RELO - Embassy of United States in Indonesia.

Larson, Kasey R.(2014). "Critical Pedagogy (ies) for ELT in Indonesia.” TEFLIN Journal, Volume 25, Number 1, January 2014. $122-138$.

Orlando, Maria. (2013). Nine Characteristics of a Great Teacher. Faculty Focus, Higher Ed Teaching Strategies from Magna Publication. http://www.facultyfocus.com. Accessed on 20 January 2015. 